\title{
Mobile learning: teaching and learning with mobile phones and Podcasts
}

\author{
Adelina Moura \\ Universidade do Minho \\ Gualtar \\ 4710 - 057 Braga - Portugal \\ adelina8@gmail.com \\ Ana Amélia Carvalho \\ Universidade do Minho \\ aac@iep.uminho.pt
}

\begin{abstract}
Mobile learning, a natural extension of distance education, supported by wireless mobile technologies is an emerging pedagogical learning model which requires new forms of teaching and learning. Being aware of the importance of this standard, we held a series of educational experiments utilizing mobile devices such as mobile phones and MP3/MP4 players to evaluate the implications of mobile technologies in individual and collaborative learning. The preference for these technologies is the fact that they are in the students' hands and have a great potential in the education system. Among the experiments we highlighted the hearing of Podcasts on curriculum content. In this paper we present data about the students' positive perceptions of Podcasts regarding their usefulness and educational value. These allow us to draw conclusions about the educational potential of these tools.
\end{abstract}

\section{Introduction}

After making vast changes to the way that people communicate and do business, the Internet is now changing the way that people learn. In a knowledgeable society, mobility and ubiquitous learning become more relevant. From this point of view, the emerging paradigm of m-learning seems to enhance the needs of contemporary society. When we talk about m-learning we think about the mobility of learners [1].

This change in the pedagogical paradigm also requires changes in the way that educational materials are designed, developed and made available to anyone who wants to learn. It's in this context that the "learning objects" are influencing the next generation of educational designers, due to their potential of regeneration, adaptability and support. Within these concepts Podcasts appear as examples of learning objects or resources. It was in this context that we developed the Mobile Generation ${ }^{1}$ project supported by mobile devices with both large and small screens. The objective of this project was to assess the implications of mobile technologies in individual and collaborative learning. For this paper we only refer to the experiment involving mobile phones, MP3/MP4 players and Podcasts and we present the students' perceptions about the use of the mobile phone in education.

\section{2. m-Learning}

Changes in education are also resulting from changes in technology [2]. The development of mlearning as a new strategy for education has implications for the way that students learn, for the role of teacher and for educational institutions. This paradigm has led to discussion about how the process of learning is developed in an educational environment which is supported by mobile technologies. In this context students have more autonomy because they can learn when and where they want, however, this model raises some questions that do not arise in the traditional pedagogical model and these need investigation.

\section{Cell phones in an educational context}

Of all the different types of mobile devices cell phones are the most popular with the young. Though

\footnotetext{
${ }^{1} \mathrm{http}$ //geramovel.googlepages.com
} 
there are still some technical problems with providing content through the phone, because of the small screen size. Anyway, the phone is well suited to such activities as sending SMS reminders to students about dates, quizzes, video and audio files storage. All of these help the student to study anytime, anywhere [3].

\section{Podcast: to learn anywhere and anytime}

Since 2005, users have been able to easily get automatic updates of recent podcasts [4] and the emergence of portals such as Podomatic, have allowed any user to write and publish their podcasts for free. These conditions provided a generalization of this technology, and led us to create our podcasts of Portuguese literature. Thus, the students have Portuguese lectures on audio files available and they can easily download it, for their mobile devices (phone, MP3 and MP4), and listen to them when and where they wish.

\section{Study Description}

For this study we created diversified activities to be conducted with mobile devices. The objectives of these activities were to allow an effective use of mobile technologies in the curriculum and give students the opportunity to learn at their own pace and time and location.

\subsection{Sample Characterization}

This study included 15 students (boys) from a class of the Public Professional Education of Carlos Amarante Secondary School, in Braga - Portugal.

Based on a questionnaire regarding the ownership of mobile devices, it was found that all students have a mobile phone, $67 \%$ of them have MP3 player and only $27 \%$ have MP4 player. The possession of these mobile devices met the minimum conditions necessary for the development of curricular activities offered to the students.

\subsection{Instruments of data collection}

Two questionnaires were developed, both of which were completed at the end of the study. The first, called "The cell phone in an educational context", the second named "Attitudes of pupils to the use of Podcasts about the Baroque Style". We wanted to analyze information about the general use of Podcasts and about the perception of the students regarding this tool in support of the study of curricular material, for that we adapted some existing data collection instruments [5].

\section{Data Analysis}

The data presented below focuses on the first and third part of the first questionnaire, aimed at evaluating the use of the cell phone in an educational context and the data collected through the second questionnaire that intended to examine the attitudes of students on the use of Podcasts.

\subsection{Using the cell phone in school}

Regarding the students' perception of the implementation of the cell phone in school (table 1), the majority of them $(66 \%)$ considered that the cell phone aids collaborative work, provides motivation for school activities (73\%), allows quick access to course material (73\%) and allows necessary information to be accessed at any time and anywhere (73\%).

Table 1. Mobile phone used in school $(\mathrm{N}=15)$

\begin{tabular}{|l|c|c|c|c|c|c|}
\hline \multirow{2}{*}{ Item } & \multicolumn{2}{|c|}{ Disagree } & \multicolumn{2}{c|}{ Undecided } & \multicolumn{2}{c|}{ Agree } \\
\cline { 2 - 7 } & f & $\%$ & f & $\%$ & f & $\%$ \\
\hline $\begin{array}{l}\text { Aids collaborative } \\
\text { work }\end{array}$ & 1 & 7 & 4 & 27 & 10 & 66 \\
\hline $\begin{array}{l}\text { Motivates for school } \\
\text { activities }\end{array}$ & 0 & 0 & 4 & 27 & 11 & 73 \\
\hline $\begin{array}{l}\text { Allows quick access } \\
\text { to course material }\end{array}$ & 0 & 0 & 4 & 27 & 11 & 73 \\
\hline $\begin{array}{l}\text { Allows information to } \\
\text { be accessed at any } \\
\text { time and anywhere }\end{array}$ & 0 & 0 & 4 & 27 & 11 & 73 \\
\hline
\end{tabular}

\subsection{Students' attitude toward the use of Podcasts about the Baroque}

The data presented below refer to the second questionnaire that asked about the students' attitude to the use of Podcasts about the study of the Baroque Style.

\subsubsection{Students' perceptions about the Baroque Podcasts}

The following data is related to the students' attitude towards the Podcasts (table 2). Only $20 \%$ of students considered that by using Podcasts they didn't need to attend Portuguese classes, 33\% believe that Podcasts can replace the teacher and the majority $(57 \%)$ of them are undecided about whether they prefer to listen to Podcasts or hear the teacher explain the subjects in class. The majority (53\%) found the repeatability of Podcasts to be beneficial. Only $20 \%$ of students said 
they preferred to read the course material than to listen to it.

Table 2. Students' attitude towards Podcasts $(\mathrm{N}=15)$

\begin{tabular}{|l|c|c|c|c|c|c|}
\hline \multirow{2}{*}{ Item } & \multicolumn{2}{|c|}{ Disgree } & \multicolumn{2}{c|}{ Undecided } & \multicolumn{2}{c|}{ Agree } \\
\cline { 2 - 7 } & f & \% & f & \% & f & $\%$ \\
\hline $\begin{array}{l}\text { With podcasts I do not } \\
\text { need to attend } \\
\text { Portuguese classes }\end{array}$ & 5 & 33 & 7 & 47 & 3 & 20 \\
\hline $\begin{array}{l}\text { Podcasts replace the } \\
\text { teacher }\end{array}$ & 5 & 40 & 3 & 27 & 4 & 33 \\
\hline $\begin{array}{l}\text { Repeatability of } \\
\text { Podcasts is beneficial }\end{array}$ & 1 & 7 & 6 & 40 & 8 & 53 \\
\hline $\begin{array}{l}\text { I like to read course } \\
\text { material rather than } \\
\text { hear it in podcasts }\end{array}$ & 6 & 40 & 6 & 40 & 3 & 20 \\
\hline $\begin{array}{l}\text { I prefer to hear teacher } \\
\text { explain the issues in } \\
\text { class }\end{array}$ & 0 & 0 & 8 & 57 & 7 & 43 \\
\hline
\end{tabular}

As regards the podcasts' educational value (Table 3 ) the majority of students $(80 \%)$ believe that Podcasts are a complement to the classroom, and that with them they achieve more success (53\%). Podcasts helped the students to prepare for the test $(60 \%)$, to memorize the course details (67\%) and stimulate students to learn $(66 \%)$.

Table 3. Podcasts' educational value $(\mathrm{N}=15)$

\begin{tabular}{|l|c|c|c|c|c|c|}
\hline \multirow{2}{*}{ Item } & \multicolumn{2}{|c|}{ Disagree } & \multicolumn{2}{c|}{ Undecided } & \multicolumn{2}{c|}{ Agree } \\
\cline { 2 - 7 } & f & $\%$ & f & \% & f & $\%$ \\
\hline $\begin{array}{l}\text { The podcasts are a } \\
\text { supplement to the } \\
\text { classroom }\end{array}$ & 0 & 0 & 3 & 20 & 12 & 80 \\
\hline $\begin{array}{l}\text { With podcasts, students } \\
\text { achieve more success }\end{array}$ & 1 & 7 & 6 & 40 & 8 & 53 \\
\hline $\begin{array}{l}\text { The podcasts helped } \\
\text { me to prepare for the } \\
\text { test }\end{array}$ & 0 & 0 & 6 & 40 & 9 & 60 \\
\hline $\begin{array}{l}\text { The podcasts helped } \\
\text { me to remember the } \\
\text { course details }\end{array}$ & 0 & 0 & 5 & 33 & 10 & 67 \\
\hline $\begin{array}{l}\text { The podcasts encourage } \\
\text { students to learn }\end{array}$ & 1 & 7 & 4 & 27 & 10 & 66 \\
\hline
\end{tabular}

\section{Conclusion}

It's important to continue to investigate the implications of mobile technologies in learning as a new educational model. Mobile devices are tools, which are becoming increasingly powerful and they can help teachers to create mixed educational opportunities, extending the boundaries of the classroom, thus giving students more options about the time and place to learn. Mobile technology is helping to develop new methods and resources for accessing information.
Despite the fact that students are still in the early stages of the use of mobile phones in an educational context, the data we present already shows positive perception about their usefulness and its value as a tool to support the education process. We highlight the fact that the students find all the services available in their phones to be easy to use, especially the newer features such as the internet, MSN, GPS, and email. In the future teachers and students will no longer have to be restricted to a place and a time to teach and learn. Mobile devices and wireless technologies will, in the near future, become routine both inside and outside the classroom.

We intend to continue to develop content for mobile phones with appropriate copyright and free software.

\section{References}

[1] Kukulska-Hulme, A. Introduction. In KukulskaHulme, A. \& Traxler, J. (eds), Mobile Learning: A Handbook for Educators and Trainers, Routledge, London, 2005, pp. 1-6.

[2] Nelson, L. M. Collaborative problem solving. In C. M. Reigeluth (Ed.), Instructional theories and models: A new paradigm of instructional theory (2nd edition) Lawrence Erlbaum, Mahwah, NJ, 1999, pp. 161-181.

[3] Thornton, P., Houser, C. M-Learning: learning in Transit. In Lewis, Paul (Ed.). The Changing Face of Call: A Japanese Perspective. Taylor \& Francis, 2002, pp. 229-244.

[4] Chartrand, R. \& B. Pellowe . ELTPodcast.com A Podcast and Website for Students and Teachers of English. In Thomas, M. (ed.), Wireless Ready eProceedings - Podcasting Education and Mobile Assisted Language Learning, 2007, pp. 66 - 72.

[5] Moura, A. \& Carvalho, A. Podcast: para uma aprendizagem Ubíqua no Ensino Secundário. In Alonso, L. P. et al (eds), Vol 2: 8th Internacional Symposium on Computer in Education. Universidad de León, León, 2006, pp. 379-386. 